\title{
POLITICO-ADMINISTRATIVE INTERFACE IN THE LOCAL COORDINATION OF BANGLADESH: A LITERATURE REVIEW
}

\author{
Md. Mashiur Rahman \\ Associate Professor, Department of Public Administration, \\ Comilla University, Comilla-3506, Bangladesh \\ $\& \mathrm{PhD}$ student under School of Public Affairs \\ University of Science and Technology of China (USTC). \\ Address: University of Science and Technology of China. \\ 96 JinZhai Road Baohe District, Hefei, Anhui, 230026, P. R. China. \\ E-mail: mashiur@mail.ustc.edu.cn
}

\section{Fahad Asmi}

PhD student under School of Public Affairs University of Science and Technology of China (USTC), Address: University of Science and Technology of China. 96 JinZhai Road Baohe District, Hefei, Anhui, 230026, P. R. China. E-mail: fasmie@mail.ustc.edu.cn

\section{Salma Nasrin}

Master student under School of Public Affairs University of Science and Technology of China (USTC). Address: University of Science and Technology of China. 96 JinZhai Road Baohe District, Hefei, Anhui, 230026, P. R. China. E-mail: nasrin@mail.ustc.edu.cn (Corresponding author)

\begin{abstract}
The purpose of the study is to review the history of politicization in local government (LG) and determine the major factors that affect local coordination in Bangladesh maintaining the relationships between politics and administration under the changing provisions of the Upazila Parishad (UZP) Act of 2009 and the partisan LG provisions of 2015. The study is entirely based on a literature review where only qualitative data has been explored. Eighteen documents were selected as a data set through searching Web of Science, SCOPUS and Google Scholar databases by using the relevant key-words. The study found a number of factors that are outlined by inter- and intra-organizational perspectives which negatively effect on local coordination in Bangladesh. Among these factors, lack of proper division of work, financial dependency on central government, lack of a chain of command among LG bodies, and the compulsory advisory role of Member of the Parliament (MP) over UZP are found to be major inter-organizational factors, whereas dual loyalty of transferred departments, unequal project distribution among Union Parishads (UP), and the domination of non-elected members in UZP are also identified as intra-organizational factors that are negatively associated with local coordination. Despite these existing problems, recently adapted partisan LG provisions are also creating a huge conflict in not only the local administration but also in local politics. In this regard, the government will have a great opportunity to address these burning issues properly through removing these legal and practical barriers for ensuring better local coordination.
\end{abstract}


Keywords: politics-administration; local government; local coordination; Upazila Parishad (UZP); Upazila Nirbahi Officer (UNO); member of the parliament (MP).

Citation: Rahman, Md. M, Asmi, F. \& Nasrin, S. (2018). Politico-Administrative Interface in the Local Coordination of Bangladesh: A Literature Review. Public Administration Issue, Special Issue II (electronic edition), pp. 134-158 (in English); DOI: 10.17323/1999-5431-2018-0-6-134-158

\section{Statement of the issues}

\section{Politics-administration interface}

Every state will have to delegate some of its public services to the local authorities that are geographically located in different places in the country and this may happen in different forms. According to Rondinelli $(1981 ; 1992)$, these types of delegated power and responsibilities are renowned as decentralization and it is divided into four forms. Among these forms, 'Deconcentration' means to transfer the functions within a centrally controlled hierarchical authority, 'Delegation' means to transfer the functions to the bodies with some discretionary powers, 'Devolution' means to transfer the functions with decision making power to local government organizations, and 'Privatization' means to transfer the power and responsibility to the non-governmental organizations (cited in Jacobsen, 2003). Here, the degree of central control is found to be the main dissimilarity between these forms of transfer \& delegation. The relationship between politics and administration considering power distribution is a well-known classical concept in the history of political science. Originally, the politics-administration dichotomy concept was developed by a scholarly article of Woodrow Wilson in 1887 where the main functions of politics were limited to formulating policy and the main notion of administration was to implement the policy at the different levels of administration (cited in Jahan \& Shahan, 2008; cited in Jacobsen, 2003). Politics, according to Weber, was all about choosing between values, and administration, on the other hand, was all about facts (Jacobsen, 2003). Herbert Simon's 'Administrative Behavior (1976)' was the first scholarly paper to oppose the Weberian ideal model where he did not totally obliterate the distinction between fact and values, but argued strongly that many decisions could be characterized as both factual and ethical (cited in Jahan \& Shahan, 2008; Jacobsen, 2003).

According to Woodrow Wilson, politicians should concentrate on strategic and principled tasks, whereas technical tasks should be delegated to the administration that was opposed by Mosher (1982) who argued strongly that it was impossible to analyze public tasks only in technical terms. Finer (1941) and Friedrich (1940) disagreed with politics-administration separation and they opined that politics could not be separated into different phases, but rather it was tightly connected in different segments. However, the line between politics and administration becomes more or less unclear. Therefore, Svara (1985; $1998 ; 1999 ; 2001 ; 2006)$ who describes the limits of the politics-administration dichotomy and also puts forward the complementarity model where elected rep- 
resentatives (politics) and bureaucrats (administration) join together in the mutual pursuit of good governance. Today, the idea of a total separation between politics and administration is impossible to consider. Now the administration is contributing their role in policy formulation with their regular work through providing policy input and having a presence in policy meetings with politicians (Jacobsen, 2003). On the other hand, the politicians expanded their hands in the policy implementation process too. As a result, the overlapping of politics and administration has created an opportunity of cooperation, competition and conflict among themselves (Spicer, 2015; Jacobsen, 2003).

\section{Central government control over politics-administration relations at local level}

There are numerous legitimate arguments for both centralization and decentralization (Phillips, 1996; Page, 1991; Ali, 1987) in the political system of governance. However, it is more common to argue that decentralization of political power and responsibilities will enhance the general interest in local politics and accommodate the active participation of local citizens. On the other hand, local level decisions that are based on local knowledge and the involvement of local people comprehend local needs and demand (Jacobsen, 2003). In that sense, the service delivery and distribution system enjoys better in a decentralized system. Small units may also have fewer problems to coordinate via the local affairs and effectiveness and efficiency may be better through a decentralized system (Hagen \& Sørensen, 1997). Moreover, politics and administration are also highly interdependent, where administrators are dependent on political decisions towards funds allocation and legal orders, on the other hand, politicians are dependent on policy input and advice from administrators for better future policy formulations (Ahmed, 2009; Jacobsen, 2003).

In the last three decades, many developed countries have focused on establishing their bureaucracies into horizontal and vertical specializations (Rahman, 2015). As a result, public service delivery was transferred from the central government to many autonomous bodies, field administrations and local government bodies (Whettenhal \& Thynne, 2010; Radaelli, 2008; Morshed, 1997). Thus, local government is functioning prevalently all over the world and bureaucracy is also working at local levels with locally elected politicians. But the experiences of many developing countries provide plenty of evidence that there are a lot of confrontations and coordination problems between locally elected politicians and government officials regarding local policy formulation and implementation (Rahman, 2013; Ahmed et al., 2011; Huque, 1988; Ahmed, 1980).

\section{Central-local government relations in Bangladesh}

The central government of Bangladesh has the authority to fix the territorial boundary, composition, manpower, function, and the mechanism of dispute-settlement with other organizations, as well as financial matters including budget, revenue sources and ceiling, expenditure pattern, inspection regulation, removal mechanism of representatives, and separate rules on the 
implementation, facilities, and duties of Upazila Parishad (UZP) ${ }^{1}$ through formulating the act, schedule, rules, guidelines, charter and circulars (Ahmed \& Rahman, 2012). Apart from this, the UZP Act provides opportunities to central government not only to allocate funds for various development activities but also dictates on the procedure of its spending (Rahman, 2015; Sowdagar, 2010). Moreover, the central government primarily exercises its control over UZP through its field level officers such as the Deputy Commissioner (DC) and the Upazila Nirbahi Officer (UNO) ${ }^{2}$, heads of district and Upazila ${ }^{3}$ administration respectively. Besides that, UZP has to spend the money in the particular sector like education, agriculture, and physical structure determined by the central government based on population and a vaguely defined criteria of backwardness (As-Saber \& Rabbi, 2009). In this context, UZP has no power to reallocate the money from one sector to another (Zafarullah, 2005) which constrains the scope of responsiveness to local needs.

Central government includes the Member of the Parliament $(\mathrm{MP})^{4}$ of that constituency, the UNO who is the coordination and supervision officer of the central bureaucracy at Upazila level, as well as the principal executive officer (PEO) of the UZP, 'transferred departments's officers and officers of 'retained departments' ${ }^{3}$. At the moment, a transferred department's officer has to be accountable not only to UZP but also to their own superior officials. But in the case of retained departments, the UNO plays a coordinator role but local government has almost zero power over retained departments. According to the amendments of 2009 and 2011 to the UZP Act 1998, the MP of that constituency is the compulsory adviser to UZP and he/she will be invited to every meeting of UZP. As per the rules, UZP needs to inform or send a copy to the MP of all communication with central government, needs to take recommendations from the MP about preparing five year and other development plans, and also needs to send a copy of the budget to the MP (Rahman, 2013; Ahmed \& Rahman, 2012). So, it seems that although the MP is an elected representative of the legislature, the provision of the UZP act has created an opportunity for the MP to participate

\footnotetext{
1 UZP is the mid-tier of rural local government in Bangladesh where it is formed by a direct election. In this study, UZP represents as 'Politics'. According to the UZP Act, UZP is the supreme authority at Upazila over transferred departments.

2 In Bangladesh the Upazila Nirbahi Officer, often abbreviated as UNO, is the chief executive of an Upazila (sub-district) and a mid-level officer of the Bangladesh Civil Service (Administration Cadre). In this study the UNO, as the head of local Bureaucracy, acts as 'Local Administration'.

3 Upazila (Sub-district), formerly called Thana, is a geographical region in Bangladesh working for administrative or other purposes.

4 A member of parliament (MP) is the representative of the voters to a parliament who is involved with the policy formulation and explanation. In this study, MP represents the role of 'Politics'.

5 According to the Article 24(1) (b) of the Upazila Parishad Act-1998 (Amended up to 2009) thirteen officers of the central government at the Upazila level with their subordinates and offices are transferred to the Upazila Parishad. Transferred officers are 1) Upazila Nirbahi Officer-UNO and the Upazila level officer of the following departments: 2) agriculture, 3) livestock, 4) fisheries, 5) youth development, 6) social welfare, 7) health and family planning, 8) family planning, 9) primary education, 10) women affairs, 11) project implementation, 12) public health engineering, and 13) local government and engineering, these are transferred departments. In this study, these thirteen officers are considered as part of the 'Local Administration'.

${ }^{6}$ Other than earlier stated thirteen departments all other departments at the Upazila level are retained departments, where UZP has limited access.
} 
and interfere in every activity of UZP. Although MPs fiercely resisted the introduction of UZP earlier, they are now the chief benefactors of this organization as well as masters of all development activities (Rahman, 2014). Interestingly, the bad relationship exists not only with the representatives of opposition political parties but also with the same political party (Panday, 2014; Ahmed \& Rahman, 2012). Therefore, the central government also exercises substantial financial and administrative control over local governments in different ways. Mutebi (2004) found that these excessive regulatory and bureaucratic controls over the UZP resemble what was termed as the recentralization of Thailand (cited in: As-Saber \& Rabbi, 2009).

\section{Scope \& Rationale of the study}

The study area is limited to UZP coordination whereas all transferred departments including the UNO have to perform their duties under an elected UZP and the MP will have an advisory role over UZP. In this context, this study is confined to comprehending the relationships among UZP Chairman (UZPC), the UNO and the MP in UZP coordination activities.

Figure I

\section{Current structure of Upazila Parishad in Bangladesh}

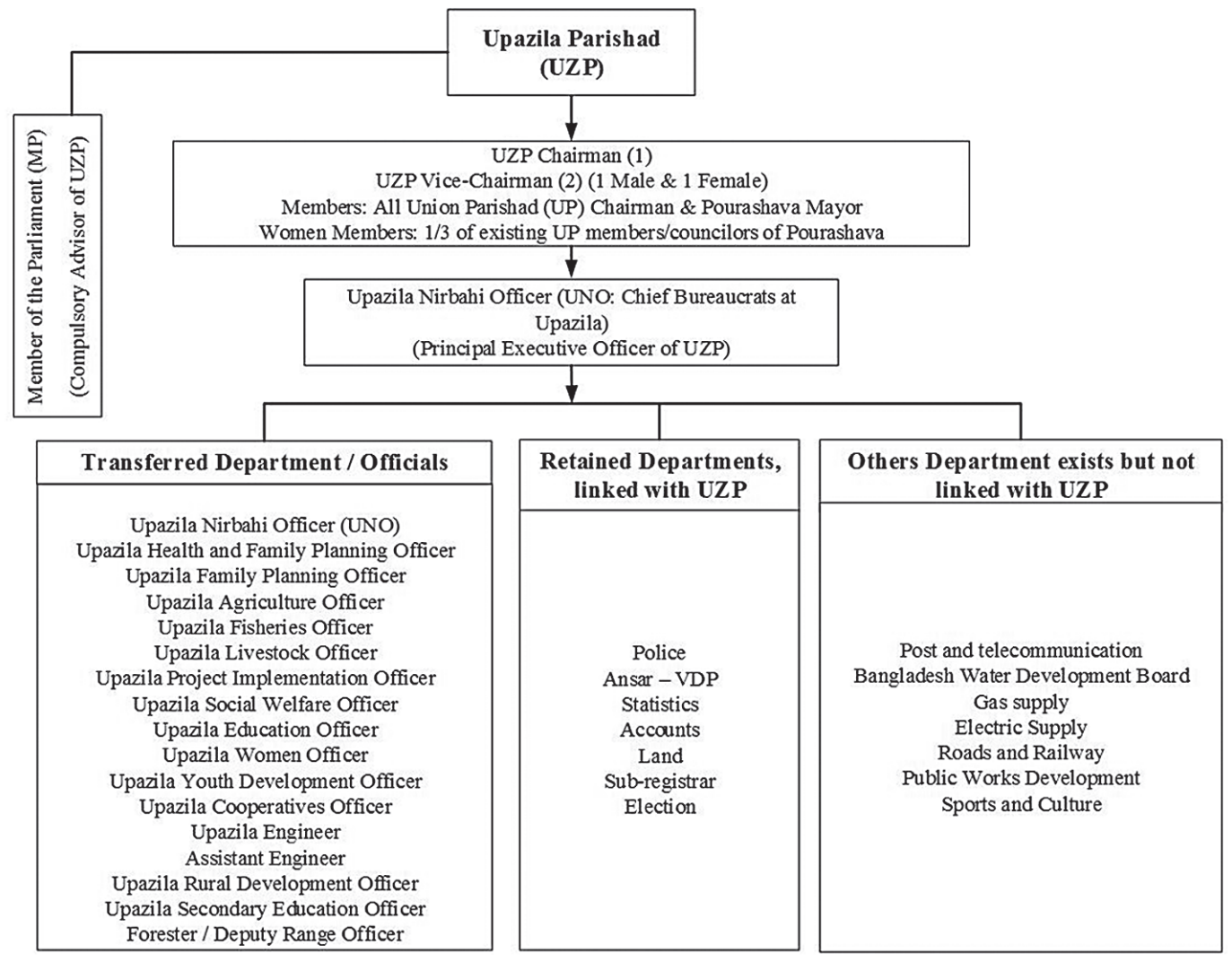

Own Illustration, 2018 
In Bangladesh some attempts have already been made to understand the structural and administrative dimension of the problems of coordination in the Upazila administration. But after adopting two recent major changes, i.e. the amendments of 2009 and 2011 to the UZP Act of 1998 and the partisan provisions of local polls in 2015, there was a dramatic change in local coordination. However, previous research was conducted mostly before 2009 when there was no elected UZP and nonpartisan LG bodies. Therefore, we found a couple of recent researches on politicsadministration relations at local level in Bangladesh (Rahman, 2012; 2013; 2014; Ahsan \& Panday, 2013) but these are not enough to accommodate inter- and intraorganization perspective together including the effect of partisan local representatives towards local coordination. Besides, the factors associated with poor local coordination that was explored through different studies are scattered and have limited coverage. So, the purpose of the study is to review the history of the politicization of local government and find out, through a rigorous literature review, the factors that affect local coordination maintaining the relationships between politics and administration under the changing provisions of the UZP Act and partisan local government provisions.

\section{Pre-understanding of the theoretical standpoints}

There is a growing body of literature in public administration and organizational studies that critically addresses the study of coordination. Harold Siedman (1998) rightly observed that coordination is indeed the philosopher's stone of public administration (cited in Kettl, 2003). Malone and Crowston (1994) stated that 'Coordination is managing dependencies between activities'. Seidman and Gilmour (1986) define coordination as 'both a process of the act of coordinating and a goal of the bringing together of diverse elements into a harmonious relationship in support of common objectives' (cited in Jennings, 1994). Robinson et al. (2000) have identified three ideal types of IORs: coordination, cooperation and competition that is closely matched with the inter-organizational coordination scenario in the local development of Bangladesh. Robinson et al. (2000) identified coordination as 'the description of relationships which are ordered by the exercise of authority through hierarchy and rules, rather than by the hidden hand of competition or by solidarity based on trust and reciprocity'. Mintzberg (1979) argues that when organization becomes simple to complex and from stable to dynamic, there is a need for different modes of intra-organizational coordination i.e., (1) mutual adjustment, (2) direct supervision, (3) standardization of work, (4) standardization of outputs, and (5) standardization of skills. Among these, mutual adjustment achieves the coordination of work through the simple process of informal communication where direct supervision achieves coordination by having one individual taking responsibility for the work of others. In this regard, work processes are standardized when the contents of the work are specified. In this study, the intra-organizational coordination has been used to denote the existing working relationship among different departments within UZP in Bangladesh. Svara (1985; 1998; 1999; 2001; 2006) describes the limits of the politics-administration dichotomous view and also puts forward the complementarity model, which is supported by several empirical stud- 
ies (Demir \& Reddick, 2012; Hansen \& Ejersbo, 2002). The Complementarity Model is based on the premise that elected representatives and bureaucrats join together in the mutual pursuit of good governance, resulting in a high level of interaction, reciprocal influence, cooperation and trust (Svara, 2001; 2006; Mouritzen \& Svara, 2002). In this perspective, the present study emphasizes how the politicians and bureaucrats maintain their mutual relationships to plan and implement local projects together, which shows the essence of the complementarity model.

\section{Methodology of the study}

The study is based on a comprehensive literature review where qualitative data has been considered. According to Perri 6 and Bellamy (2012), data creation methods refer to the procedure of constructing raw material for advance investigation. In this context, data was created through reviewing literature, which included textbooks, peer-reviewed articles and some most relevant reports. The articles were sourced through the 'Web of Science' and the 'SCOPUS' databases which are accessed by the University of Science and Technology of China that was extended to Google Scholar as enough relevant articles could not be found through selected databases. At first, we searched from both databases by using the following keywords where the literature search filtered the time between 1980 to February 2018, we searched only through 'Title', the document type was 'Article', language in 'English', and the research domain/subject area was 'Social Sciences'. Subsequently, we found 96 articles from Web of Science and 62 articles from SCOPUS by utilizing the following key words. After reviewing the article's abstract and findings, we found 13 articles that are more relevant to the scope of this study, among them two were overlapped in both databases. As a result, 11 articles from these two databases were finalized as the data set in this study.

Table 1

Data creation procedure

\begin{tabular}{|l|c|c|c|}
\hline \multicolumn{1}{|c|}{ Keywords } & Database & $\begin{array}{c}\text { Article/ } \\
\text { Documents Found }\end{array}$ & $\begin{array}{c}\text { Relevant } \\
\text { Documents }\end{array}$ \\
\hline \multirow{2}{*}{ Local Coordination } & Web of Science & 74 & 00 \\
\cline { 2 - 4 } & SCOPUS & 28 & 00 \\
\hline \multirow{2}{*}{$\begin{array}{l}\text { Local Coordination } \\
\text { in Bangladesh }\end{array}$} & Web of Science & 00 & 00 \\
\cline { 2 - 4 } & SCOPUS & 00 & 00 \\
\hline \multirow{2}{*}{$\begin{array}{l}\text { Politics-Bureaucracy } \\
\text { Relations }\end{array}$} & Web of Science & 01 & 01 \\
\hline \multirow{2}{*}{ Politics-Administration } & SCOPUS & 00 & 00 \\
\cline { 2 - 4 } & Web of Science & 12 & 00 \\
\hline \multirow{2}{*}{$\begin{array}{l}\text { Field Administration } \\
\text { in Bangladesh }\end{array}$} & SCOPUS & 15 & 00 \\
\cline { 2 - 4 } & Web of Science & 00 & 00 \\
\hline
\end{tabular}




\begin{tabular}{|c|c|c|c|}
\hline Keywords & Database & $\begin{array}{c}\text { Article/ } \\
\text { Documents Found }\end{array}$ & $\begin{array}{c}\text { Relevant } \\
\text { Documents }\end{array}$ \\
\hline \multirow{2}{*}{$\begin{array}{l}\text { Local Government } \\
\text { in Bangladesh }\end{array}$} & Web of Science & 07 & 0 \\
\hline & SCOPUS & 11 & 05 \\
\hline \multirow{2}{*}{$\begin{array}{l}\text { Politics of Administrative } \\
\text { Decentralization }\end{array}$} & Web of Science & 02 & 01 \\
\hline & SCOPUS & 03 & 01 (Repeat) \\
\hline \multirow{2}{*}{$\begin{array}{l}\text { Role of the Members } \\
\text { of Parliament in the Local } \\
\text { Government }\end{array}$} & Web of Science & 00 & 00 \\
\hline & SCOPUS & 01 & 01 \\
\hline \multirow[t]{2}{*}{ Upazila Parishad } & Web of Science & 00 & 00 \\
\hline & SCOPUS & 00 & 00 \\
\hline \multirow[t]{2}{*}{ Upazila Administration } & Web of Science & 00 & 00 \\
\hline & SCOPUS & 02 & 02 (01 Repeat) \\
\hline Total & & & 11 \\
\hline
\end{tabular}

After that, we searched again through Google Scholar by using the same key words, expecting more relevant literature. We found a good number of articles, books, unpublished thesis, and reports related to politics-administration relations at local level in Bangladesh. But after reviewing those documents, seven more documents ( 3 articles, 2 books, 1 report, and 1 unpublished thesis) were selected that were also the most relevant within the scope of this study. In total, $18(11+7)$ pieces of literatures were finalized for the data set of this study as shown below:

Table 2

\section{Selected data set of the article}

\begin{tabular}{|c|l|l|l|}
\hline $\mathbf{N}$ & \multicolumn{1}{|c|}{ Article/Thesis/Books Name } & Author's Name & Journal/Publisher Name \\
\hline 1 & $\begin{array}{l}\text { Bureaucratic Perceptions to the } \\
\text { Politics-Bureaucracy Relations } \\
\text { in Bangladesh: A Moral Dilemma } \\
\text { in between Political Neutrality } \\
\text { and Responsiveness. }\end{array}$ & Rahman (2014) & $\begin{array}{l}\text { Asian Journal of Political } \\
\text { Science }\end{array}$ \\
\hline 2 & $\begin{array}{l}\text { Problems of Coordination in Field } \\
\text { Administration in Bangladesh: Does } \\
\text { Informal Communication Matter? }\end{array}$ & Ahsan \& Panday (2013) & $\begin{array}{l}\text { International Journal } \\
\text { of Public Administration }\end{array}$ \\
\hline 3 & $\begin{array}{l}\text { Role of the Members of Parliament } \\
\text { in the Local Government of } \\
\text { Bangladesh: Views and Perceptions } \\
\text { of Grassroots in the Case of Upazila } \\
\text { Administration. }\end{array}$ & Rahman (2013) & $\begin{array}{l}\text { Public Organization } \\
\text { Review }\end{array}$ \\
\hline 4 & $\begin{array}{l}\text { Annual Development Programme } \\
\text { (ADP) Grants for Upazila Parishads: } \\
\text { Role of Upazila Nirbahi Officer } \\
\text { (UNO) in the Planning and } \\
\text { Implementation Process. }\end{array}$ & Zamil (2012) & $\begin{array}{l}\text { http://www.mppg-nsu.org/ } \\
\text { attachments/396_Zamil.pdf }\end{array}$ \\
\hline
\end{tabular}




\begin{tabular}{|c|c|c|c|}
\hline $\mathbf{N}$ & Article/Thesis/Books Name & Author's Name & Journal/Publisher Name \\
\hline 5 & $\begin{array}{l}\text { Upazila Parishad in Bangladesh: } \\
\text { Roles and Functions of Elected } \\
\text { Representatives and Bureaucrats }\end{array}$ & Rahman (2012) & $\begin{array}{l}\text { Commonwealth Journal } \\
\text { of Local Governance }\end{array}$ \\
\hline 6 & $\begin{array}{l}\text { Working of Upazila Parishad } \\
\text { in Bangladesh: A Study of Twelve } \\
\text { Upazilas. }\end{array}$ & Ahmed et al. (2011) & $\begin{array}{l}\text { Local Governance Cluster, } \\
\text { UNDP }\end{array}$ \\
\hline 7 & $\begin{array}{l}\text { Some Neglected Aspects } \\
\text { of Performance in Field } \\
\text { Administration in Bangladesh. }\end{array}$ & Huque (2011) & $\begin{array}{l}\text { International Journal } \\
\text { of Public Administration }\end{array}$ \\
\hline 8 & $\begin{array}{l}\text { Reintroducing Upazila system } \\
\text { in Bangladesh: Quest for Autonomy. }\end{array}$ & Sowdagar (2010) & Development Compilation \\
\hline 9 & $\begin{array}{l}\text { Bureaucracy and local politics } \\
\text { in Bangladesh: A study in roles } \\
\text { and relationship. }\end{array}$ & Ahmed (2009) & $\begin{array}{l}\text { AH Development } \\
\text { Publishing House, Dhaka }\end{array}$ \\
\hline 10 & $\begin{array}{l}\text { Democratisation of the Upazila } \\
\text { Parishad and Its Impact on } \\
\text { Responsiveness and Accountability: } \\
\text { Myths versus Realities. }\end{array}$ & As-Saber \& Rabbi (2009) & JOAAG \\
\hline 11 & $\begin{array}{l}\text { The Politics of Administrative } \\
\text { Decentralization in Bangladesh. }\end{array}$ & Rashid (2005) & $\begin{array}{l}\text { Canadian Journal } \\
\text { of Development Studies }\end{array}$ \\
\hline 12 & $\begin{array}{l}\text { Bureaucratic Response } \\
\text { to Administrative Decentralization: } \\
\text { A Study of Bangladesh Civil Service. }\end{array}$ & Morshed (1997) & $\begin{array}{l}\text { The University Press } \\
\text { Limited, Dhaka }\end{array}$ \\
\hline 13 & $\begin{array}{l}\text { Local Government in Bangladesh: } \\
\text { Past Experiences and Yet Another Try. }\end{array}$ & Westergaard \& Alam (1995) & World Development \\
\hline 14 & $\begin{array}{l}\text { Problems of co-ordination in Upazila } \\
\text { Administration in Bangladesh }\end{array}$ & Ahmad (1991) & $\begin{array}{l}\text { Public Administration } \\
\text { and Development }\end{array}$ \\
\hline 15 & $\begin{array}{l}\text { Experiments in Local Government } \\
\text { Reform in Bangladesh. }\end{array}$ & Ahmed (1988) & Asian Survey \\
\hline 16 & $\begin{array}{l}\text { Decentralization for Development: } \\
\text { Experiment in Local Government } \\
\text { Administration in Bangladesh. }\end{array}$ & Ali (1987) & Asian Survey \\
\hline 17 & $\begin{array}{l}\text { The problem of coordination } \\
\text { in Upazila Administration: } \\
\text { A case study of two Upazilas. }\end{array}$ & Huq et al. (1987) & $\begin{array}{l}\text { Bangladesh Public } \\
\text { Administration } \\
\text { Training Center }\end{array}$ \\
\hline 18 & $\begin{array}{l}\text { The politics of local government } \\
\text { reform in rural Bangladesh }\end{array}$ & Huque (1985) & $\begin{array}{l}\text { Public Administration } \\
\text { and Development }\end{array}$ \\
\hline
\end{tabular}

\section{Discussion and Analysis}

\section{Political Experimentation over Local Government in Bangladesh}

Pre-British Era. According to the Rig Veda, the ancient Indian Subcontinent was politically divided into numerous sovereign territories headed by a local King or Rajas. Self-governing village communities, i.e. the Panchayat 
system, had been characterized in India by agrarian based economies during the sixth to ninth centuries (Siddiqui, 2005). This body was composed with the position of headman and Panchayats where central government control was marginal and they had adequate financial resources to perform their duties (Khan, 2016). During the Gupta period (200-500 BC), there were two types of local councils found, the Vishays (Districts) and Bhuktis (Divisions). But strong central government control was found in Bengal during Pala \& Sena rule in the $8^{\text {th }}$ century. Moreover, the Mughal rulers emphasized to towns that was included a number of wards (Mohallas) and they did not interfere in the early customs of village government but rather they incorporated the village into the administration as a unit for collecting revenue and maintaining law and order (Siddiqui, 2005).

British Era. A loyal landed class of Zaminders had been vanished in the rural organizations of Bengal through the Permanent Settlement Act of 1793 and it provided the central government with a sound revenue and political support base (Ali, 1987; Blair, 1985). The Bengal Village Choukidari Act of 1870 tried to revive and establish the Panchayat system in the rural areas of Bengal with individuals (five members body) nominated by the district magistrate (Khan, 2001; Ali, 1983). However, the Bengal Local Self Government Act of 1885 created three tiers of local bodies in rural Bengal: Union Committee for a union, Local Board for a sub-division and District Board for a district. Two thirds of the members of these bodies were elected by indirect elections while the rest were nominated by the government. Therefore, the Bengal Village Self Governance Act of 1919 abolished the Chowkidari Panchayet and Union Committees and formed union boards and district boards instead of these tiers.

Pakistan Era. In the name of 'decentralization', the military government led by Field Marshal Ayub Khan launched a four-tier local government system under the 'Basic Democracy Order' in 1959 where the Union Council chairmen and members were the electors for the District council, the Provincial Assembly, the National Assembly and the President of the country (Westergaard \& Alam, 1995; Blair, 1985). Besides that, a new level of local government, 'Thana council' was established under the direct supervision of the sub-divisional officers (SDOs) where it comprised of Union Council chairman and appointed officials; district councils with the representatives elected by the Union Council chairman and appointed officials; and divisional councils with appointed officials and representatives elected by the district bodies (Panday, 2011; Siddiqui, 2005; Westergaard \& Alam, 1995).

Bangladesh Era. After reviewing the history of local government during Bangladesh period, it was noted that both the political government and the martial ruler used the LG bodies for their own sake as political weapons (Ahmed et al., 2011). As a result, a strong self-reliant local government institution is not established yet. Moreover, the government imposed various decisions over LG bodies through formulating different acts, provisions, orders etc. 


\section{Major political initiatives over local government bodies in the Bangladesh period}

\begin{tabular}{|c|c|}
\hline Era & Major Initiatives \\
\hline 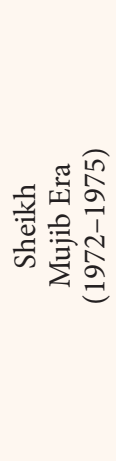 & $\begin{array}{l}\text { In 1972, the government formed the Union Panchayet instead of a Union Council } \\
\text { by incorporating the nominated members. Besides that, lawmakers along with local party } \\
\text { leaders formed the Union Relief Committee that played a vital role in distributing relief } \\
\text { materials and carrying out construction and rehabilitation work (Khan, 2016; Rahman, } \\
\text { 1997). Therefore, the legislators got a great opportunity to consolidate their power } \\
\text { by keeping the citizens loyal to them but unfortunately it spoiled the government's image } \\
\text { largely due to widespread corruption of partisan relief committees (Rahman, 2013). } \\
\text { The ruling Awami League promulgated the Local Government Act } 1973 \text { which proposed } \\
\text { a three tier local government system with Union Parishad (UP), Thana Training and } \\
\text { Development Committee (TTDC) and the District Board. But within a short time, } \\
\text { the government abolished the elected local government system and introduced one party } \\
\text { system - BAKSAL (Bangladesh Krishok Shromik Awami League) - that was supplanted } \\
\text { by party machinery (Nadiruzzaman, 2008). }\end{array}$ \\
\hline 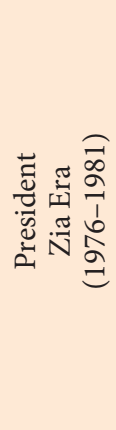 & $\begin{array}{l}\text { President Zia also continued to use local government institutions to create public support } \\
\text { and legitimacy in his favor (Nadiruzzaman, 2008). Through Local Government Ordinance } \\
\text { of 1976, a three-tier local government system, consisting of Union Parishad, Thana } \\
\text { Parishad and Zila Parishad was established but only the UP had an elected representative } \\
\text { with a Chairman and nine members. However, in 1978, Thana Development Committees } \\
\text { (TDCs) were created parallel to the Thana Parishads where the government allocated } \\
\text { special funds to the TDCs to finance development activities but TDC had to depend } \\
\text { on Thana Parishad for getting its programme approval (Ahmed, 2009; Siddiquee, 2005). } \\
\text { Huque (1988) found that President Zia introduced a new structure of rural institutions } \\
\text { in 1980, Swanirvar Gram Sarkar in 68,000 villages, downgrading the Union Parishads } \\
\text { where MPs took the leadership of Gram Sarkar Coordination Committees to ensure } \\
\text { control over the rural areas (cited in Rahman, 2013). }\end{array}$ \\
\hline 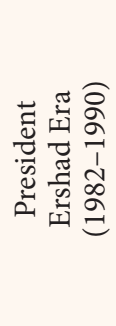 & $\begin{array}{l}\text { In 1982, President Ershad abolished the Gram Sarkar system and formed an administrative } \\
\text { reform committee, - the Committee for Administrative Reorganization/Reform (CARR). } \\
\text { According to the recommendation of the committee, subdivisions were upgraded } \\
\text { to districts and Thana was upgraded to Upazila (sub-district). The committee suggested } \\
\text { a three tier representative local government system-Zila parishad (ZP) at the district level, } \\
\text { UZP at the sub-district level and UP at the union level. Subsequently, the UZP Ordinance } \\
\text { was promulgated in 1982, which prompted the introduction of the UZP which established } \\
\text { command over local affairs in the absence of MPs. Real problems arose between UZPC } \\
\text { and MPs when a third parliamentary election was held in } 1986 \text { (Rahman, 2013). }\end{array}$ \\
\hline 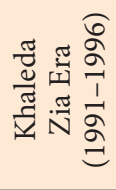 & $\begin{array}{l}\text { Khaleda Zia dissolved the UZP in 1991, and formed the Local Government Structure Review } \\
\text { Commission, which recommended a two-tier system of local government: directly elected } \\
\text { UPs and indirectly elected district-based ZPs (Sarker, 2003). The TDCC was also instituted } \\
\text { comprising chairmen of all UPs, three UP women members and government officials } \\
\text { deputed at the Upazila level. }\end{array}$ \\
\hline 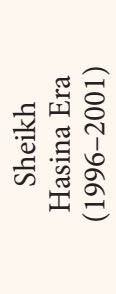 & $\begin{array}{l}\text { Sheikh Hasina made a Local Government Commission which has recommended } \\
\text { a four-tier local government system including Gram (Village) Parishad, UP, UZP and ZP. } \\
\text { The government also took up initiatives to give a formal structure to the UZP passing } \\
\text { the Upazila Act 1998, which made MPs advisers to the UZP under their respective } \\
\text { constituencies. But the government could not arrange the elections of UZP because } \\
\text { of a lack of support from the lawmakers (Ahmed et al., 2011). Besides, the government } \\
\text { made the changes in UP provisions for introducing direct elections for reserved women } \\
\text { members at UP level. }\end{array}$ \\
\hline 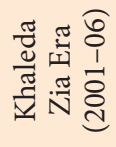 & $\begin{array}{l}\text { Gram Sarkar (GS) in place of Gram Parishad had been introduced in this era. The UP } \\
\text { member elected from the Ward was the Chairman of the GS, which had other members - } \\
\text { both male and female - elected in a general meeting of the voters of the Ward under the } \\
\text { supervision of a chairman of GS (Rashid, 2005). }\end{array}$ \\
\hline
\end{tabular}




\begin{tabular}{|c|c|}
\hline Era & Major Initiatives \\
\hline 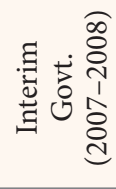 & $\begin{array}{l}\text { The interim government promulgated the Local Government (Upazila Parishad) } \\
\text { Ordinance } 2008 \text { and created a Local Government Commission to oversee the activities } \\
\text { and performance of the UZP. According to the ordinance, MPs were removed from } \\
\text { the advisory role and two new elected positions of Vice Chairpersons were created } \\
\text { (of which one must be a woman). }\end{array}$ \\
\hline 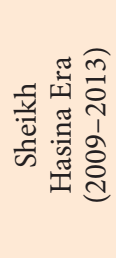 & $\begin{array}{l}\text { Sheikh Hasina did not endorse the legal changes in the parliament brought by the interim } \\
\text { government in 2007-2008. But, four acts were promulgated - the Local Government } \\
\text { (Union Parishad) Act 2009, the Local Government (Pourashava: Municipality) Act 2009, } \\
\text { One 'umbrella act' for all City Corporations in 2009, and the Local Government } \\
\text { (Upazila Parishad) Act } 1998 \text { - readopted with some revisions, and further amended } \\
\text { in } 2011 \text { paving the way for a more dominant and interfering role with the provisions } \\
\text { for making MPs compulsory advisers in the respective UZPs (Khan, 2016). }\end{array}$ \\
\hline 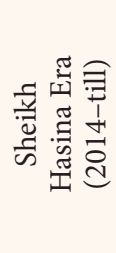 & $\begin{array}{l}\text { A paradigm shift in the political system had been taken in Bangladesh on } 12 \text { October, } 2015 \text { with } \\
\text { the final approval by the Cabinet to hold local polls on a partisan basis. Following this provision, } \\
\text { the 9th Union Parishad (UP) election was held on a partisan basis in six phases across the } \\
\text { country, from March to June 2016, for the first time in Bangladesh. Even the Zila Parishad } \\
\text { election (indirect) was held on this partisan provision for the first time. The most recent UZP } \\
\text { election was held in } 2014 \text { before passing this provision, although that UZP election was highly } \\
\text { political in nature. Recently, City Corporation elections were also held on partisan basis. }\end{array}$ \\
\hline
\end{tabular}

\section{Factors which affected local coordination in Bangladesh}

Coordination can take place either horizontally or vertically. Horizontal or interorganizational coordination can be between organizations on the same status or line, while vertical or intra-organizational coordination takes place within the organization (Malone \& Crowston, 1994). In Bangladesh, local coordination involves local elected politicians, field administration, MPs, as well as central government that entitle the importance of mutual relationships between politicians and administrators. After reviewing the selected articles and books, we found two trends of factors that affect local coordination in Bangladesh i.e. inter- and intra-organizational perspectives.

\section{Inter-organizational coordination}

Inter-organizational coordination must be considered when a policy is implemented by multiple organizations. In the present study, organizations refer to the departments of different divisions or ministries posted at Upazila level, while UZP and MPs are those who are involved in local project planning and implementation. Interorganizational coordination takes place in the context where organizations are dependent on each other and need cooperation from each other to achieve common goals. Unfortunately, we found some glitches among the bodies through reviewing the selected literatures which negatively effects on local coordination, as discussed below.

Lack of proper division of work \& role ambiguity. There is a lack of proper division of functions among the departments involved in the inter-organizational activities of UZP. In this regard, MP, UZP, Union Parishad (UP) ${ }^{7}$, and trans-

\footnotetext{
7 UP is the lowest tier of rural local government in Bangladesh where it consists of elected representatives by the voters of the respective Union. Union is the lowest territorial unit where UZP consists of a couple of Unions.
} 
ferred departments are not aware enough as to which department is responsible for what actions and how it should be executed (Ahsan \& Panday, 2013). Moreover, there is a lack of rules in an Upazila which could guide the departments involved in inter-organizational activities (Ahmed, 2010; Ahmed, 1988). UZP is authorized to approve all files and documents dealing with transferred departments as per section 14 of the UZP Act 1998. According to Section 18 of the UZP Act 1998, funds of the UZP are to be jointly operated by the UZPC and the UNO. Moreover, Section 3 of the Duties and Responsibilities Rules of UZP 2010 allows UZPC to run the routine administrative work of the UZP and supervise UZP officials but UZP cannot take any disciplinary action against the officers who are responsible for transferred subjects (GOB 2011). The role of UZP vice-chairmen is still unclear and that creates role ambiguity in UZP activities (Ahmed et al., 2011). However, the amendment in 2011 to the UZP Act tells us that the UNO has been assigned as the Principal Executive Officer of UZP where the UNO is responsible for performing all of its activities and taking steps for implementing the decisions taken by the UZP, maintain financial discipline and to discharge the responsibilities as per the rules (GOB, 2011). If the UZP found any decision to be violating the law or to be against the interest of the citizens or security, the UNO can inform the central government by keeping the UZPC informed (GOB, 2010; 2011). Section 42 (1) of the Act empowers the UZP for independent local level planning but sub section 3 of the same section empowers the MPs to become a compulsory adviser of UZP, and that creates role ambiguity between them (Sowdagar, 2010).

Financial dependency on central government. It is well known that LG bodies in Bangladesh seriously suffer from inadequate financial resources. Although Section 41 of the UZP Act 1998 empowered the UZP for the management, supervision and protection of the assets, but the valuable and resourceful assets are controlled by the central government (Sowdagar, 2010). Government' grants and special allocations are the prime source of the UZP. Besides that, the UZP has limited authority to collect revenues from particular sources such as rent from jalmahals, hats-bazaars and ferries, tax on professional and trading licenses, fees for fairs, exhibitions and tournaments, and tolls from services and facilities maintained by UZP (Rahman, 2012; Siddiqui, 2005; Ali, 1987). Although the sources seemingly look impressive, the income from these sources is very insufficient (As-Saber \& Rabbi, 2009). Major sources of revenue including income tax, customs and excise and land taxes are directly controlled by the central government (As-Saber \& Rabbi, 2009). On the other hand, elected representatives are reluctant to impose and collect local revenues for fear of losing their popularity (Sowdagar, 2010; Huque, 1992; Ahmad, 1991) as the rural citizens are not habituated enough to pay taxes (Huque, 1985). With such financial dependencies, the UZP seems to act as extended hands of the central government (Westergaard \& Alam, 1995; Ahmad, 1991). Funds under the Annual Development Programme (ADP), Block Grants, Test Relief Program, Food for Works Program, Money for Works Program, Vulnerable Group Feeding Program, Vulnerable Group Development Program, and Grotius Relief Program are disbursed by the central gov- 
ernment to the UZP, which ultimately creates a dependable UZP to the central government (Ahmed \& Rahman, 2012; Ahmad, 1991). Such dependency of UZP permits the central government to exert control over them.

Lack of chain of command among LG bodies. At present, all three tiers of rural local government in Bangladesh (ZP, UZP and UP) are assigned to manage the same nature of local affairs in their respective areas under same ministry but unfortunately there is no chain of command among these LG bodies. For the first time, elected representatives exist in all tiers of local government. On the contrary, field administration is also executing the government policies and programmes at field level where a strict chain of command is maintained among the bodies from Upazila to Secretariat level. All UP chairmen within an Upazila are the nominated members of the UZP according to the UZP Act. But UP chairmen, municipality mayor, and reserved women members dominate in UZP activities, and although they are non-elected members of the UZP, their opinion often matters more than the others (Ahmed et al., 2011). On the other hand, the UZP does not have any authority to approve the budgets of the UPs; UPs budget has to be sent to DC for approval. Moreover, UP now receives various kinds of grants from a variety of national and international sources that make it more self-reliant compared to the UZP (Ahmed et al., 2011). The UZP does not have the scope to impose something on the UP as superior bodies, and the same goes for the ZP to the UZP. The relationship among LG tiers are not found to be hierarchic, rather it is collegial that accelerates less accountability and mistrust among the bodies (Sowdagar, 2010; Huque, 1985).

Compulsory advisory role of MP over UZP. According to the UZP Act of 1998, MPs had advisory role over the UZP. But there was no opportunity to apply this advisory role until 2008 due to absence of an elected UZP. The interim government (2007-2008) undertook the UZP Ordinance of 2008 whereby it abolished the advisory role of MPs over UZP. However, Sheikh Hasina's government did not endorse the changes of the interim government's initiative on UZP and they reinstalled the compulsory advisory role of MPs again. Moreover, the concerned MP has to be made aware of any type of communication with the government by the UZP (GOB, 2011). As per the rules, MPs are elected for formulating and explaining the policy in the national parliament where local government institutions and field administration are responsible for implementing policy and government orders (Zamil, 2012; Majumdar, 2010). Although, MPs are expected to solve the general problems of citizens and improve their living standards in the context of Bangladesh (Siddiqui, 2005). But problems arose when the elected UZP was established in 2009. The UZPC were not interested or ready to receive the compulsory advice from MPs and they treated this role as interfere and disturbance in UZP activities (Rahman, 2012). Besides that MP's involvement in an advisory capacity may also create jurisdictional complications. It is mentioned that there are more than one hundred Upazila which share more than one parliamentary constituency (Ahmed et al., 2011). As a result, the UZP having to be faced with more than one adviser is likely to create chaos (The Daily Star 8 April 2009). 
Triangular conflict among MP, UZPC \& UNO. Conflict among MPs, UZPC and UNO is the major impediment towards sound and coordinated local development. Since both MPs and UZPC share same constituency in many cases and are elected by the same voters, they are likely to consider each other as competitors in regards to maintaining domination (Hossain et al., 2013; Ahmed et al., 2011). According to Section 25 of the UZP Act 1998 (amended in 2009), it is mandatory for the UZP to accept the advice and recommendation of the MPs in all development planning and activities. Such mandatory role of MPs created a great amount of frustration among the UZPC because they could not work independently (Ahsan \& Panday, 2013). As per the constitution of Bangladesh and the UZP Act, the UZPC will have authority to oversee transferred departments. In this regard, the UZPC may think him/herself the supreme authority of the Upazila as an elected representative; the MP may think that UZPC can do nothing without his/her advice and the UNO may consider him/herself as a most powerful officer of the Upazila as a Principal Executive Officer of UZP (Sowdagar, 2010). Moreover, the UNO including other officials of transferred departments are not only bound to hear the advice of UZPC according to the UZP Act, but also the UNO is liable to abide by the rules and regulations of the central government. In practice, the UNO and other officials of transferred departments are found to be loyal to the superior authority of the line ministry, compared to the UZPC (Hossain et al., 2013; Rahman, 2012). Since the MP is perceived as more powerful than the UZPC, the UNO has a negative mentality in accepting UZPC over him/her and he/she always maintains close contact with MPs (Ahsan \& Panday, 2013). As a result, the MP utilizes the UNO as an instrument for applying his influence in the Upazila.

\section{Intra-organizational coordination}

In this study, intra-organizational coordination focuses the relationships among and within the transferred departments as well as UZP functionaries. Therefore, we found couple of major intra-organizational problems through reviewing the selected literature which also negatively affects local coordination, as discussed below.

Dual loyalty of transferred departments. The objectives of decentralization aimed to place government employees into field administration to serve under the guidance of local government institutions with a view to reaching the government services from door to door (Morshed, 1997). Along with the UNO there are 13 transferred departments at the Upazila level belonging to the various cadre services that also face dual control from the UZPC as well as their respective line authorities (As-Saber \& Rabbi, 2009). As a result, the government officials found it extremely hard to meet the two interests and attachment to the line department is found stronger in most cases (Huque, 2011). As per the UZP Act, the UZPC is authorized to write an Annual Performance Report (APR) of the officials of transferred departments where their respective higher authorities are assigned to prepare ACR (GOB, 2011). Problems arise in coordination when instructions are provided by two authorities for a similar function at the same time (Ahsan \& Pan- 
day, 2013). In these cases, officials of transferred departments become confused (Zamil, 2012). As the career advancement of the officials of transferred departments depends on the superior line authority that is ensured through ACR, they are reluctant to abide by the instructions of the UZP (Ahsan \& Panday, 2013; Zamil, 2012). As a result, the delivery of services and the development work through local administration is delayed; subsequently it is difficult for officials to be accountable to the UZP (Zamil, 2012; Ahmed, 2009). However these government officers are trained and served initially under the central bureaucracy and their mental makeup adapts more to the notion of a central bureaucracy. Their loyalty to the UZP is not absolute; rather they consider their posting to the Upazila as a temporary deportation (Morshed, 1997).

Unequal project distribution among UPs. The composition of UZP is characterized by 'double mandate' where the UZPC, and UZP Vice Chairmen are elected by the voters of the respective Upazila, and the Chairmen of UPs and the Mayors of Pourashava are elected by the voters of their respective territory of Unions and Pourashava (Zamil, 2012). Moreover, each of the female members and councilors, holding reserved seats for women, are elected representatives for one particular ward only and one-third of the women members and councilors among them are also members of UZP. Considering this situation, it is found to be an organic relationship between UZP and the UPs (Zamil, 2012). However, the UZP are the key authority responsible for the five year Upazila development plan and selecting the small-scale local projects. In this way, the UZP has to consult with UPs in order to accommodate the demands and needs of the UPs. Following this, the UP submits the small scale project to the UZP through consultation among the UPs machineries. According to the rules and norms, the project should be distributed equally among the UPs on consideration of the number of populations. Unfortunately, in most cases, this does not happen. It mostly depends on personal relationships, the personal whims of the UZPC, and the political affiliation between UZPC and UP Chairman (Rahman, 2014; Ahmed, 2009) that can create mistrust and dissatisfaction between them (Zamil, 2012). Ultimately, these types of relationships hamper the coordination process in local development work.

Domination of non-elected members in UZP. According to the UZP Act of 1998, all UP chairmen and mayors of Pourashava in their respective Upazila will be the nominated member of the UZP by default, and one third of the reserved women members of all the UP and Pourashava who are elected from the all women members will also be members of the UZP, with one elected UZP Chairman and two vice-chairmen (GOB, 2011). As per the rules, every member has equal voting power in UZP activities that clearly shows the domination of non-elected members. In some cases, non-cooperation by non-elected members of the UZP utilizing their voting majority hampers development activities (Zamil, 2012). However, Section 13(A) of UZP Act of 1998, amended on December 2011, tells us that four fifths of UZP members may show a no confidence motion against UZP chairman, vice chairmen or any other member in the case of violation of the Act, serious 
misconduct or physical or mental incapacity that is also the focus the domination of non-elected members (GOB, 2011). But UP Chairmen and members are elected by the voters of their unions and wards respectively. In that sense they are accountable to the people of their respective unions and wards only and they have no accountability to the entire population of the Upazila but they do have the power to control or hamper UZP activities (Rahman, 2012).

Ineffectiveness of standing committee \& UDCC meetings. Various committees in the functioning of departmental tasks at UZP level are considered important aspects to ensure coordination. Ahsan and Panday (2013) found that the success of coordination depends largely on how frequently the meetings of a committee are held, how many members attend, how smoothly decisions are made through examining the problems faced by others, and how well they interact in the meetings. However, despite having two major committees (UDCC: Upazila Development Coordination Committee, Standing Committee) for ensuring coordination at Upazila level, coordination is not maintained properly due to the ineffectiveness of those committees (Ahmed et al., 2011). In most cases, UDCC meetings are not held regularly. When the meeting is arranged, elected representatives are found to be reluctant to attend the meeting in many cases and they rather used to make themselves busy with other works (Ahsan \& Panday, 2013). Moreover, very few problems associated with departmental tasks are discussed in this meeting. Apart from the UDCC, there is a provision to form 14 standing committees for preparing the departmental project and coordinating inter and intra-departmental functions according to Article 29 of the UZP Act, 1998 (as amended in 30 June 2009). Unfortunately, these committees are limited to paperwork in most cases, and even the meetings of this committee are not held regularly (Ahmed et al., 2011). Although UZP should take the project proposal from standing committees, in practice, the UZPC dominates the selection of a project by ignoring the standing committees. Consequently, regular and fruitful discussions among the members do not take place either in the UDCC or in standing committees due to the suffering from the problem of absenteeism and the dominating role of elected representatives (Ahmed et al., 2011).

Generalist-specialist conflict. The dominating role of the generalist officer in the administration has placed the UNO in the key position of Upazila administration of Bangladesh. On the contrary, the specialist officers (i.e. medical, education, agriculture, fisheries, engineering etc.) have to work under generalist officers like the UNO at Upazila administration, although they are selected into the civil service through the same examination (Ali, 1987; Huque, 1985). It is also well known in Bangladesh that most of the meritorious students study in scientific and technical subjects, but unfortunately if they want to work in their respective field, they have to perform under generalist cadres (Zamil, 2012; Ahmad, 1991). Such dominance of the generalist cadres and the sense of deprivation of the specialists officials are the main cause of generalist-specialist conflict in the Bangladesh civil service (Ahsan \& Panday, 2013; Ahmed, 1988). However, the specialists do not want to be controlled and coordinated by the 
generalists like the UNO at Upazila level who are junior to them in the most cases (Ahmad, 1991). Besides that, officials who belong to the administration cadre' consider themselves as the elite class in the public service. Thus, professional jealousy, service superiority as well as the dominating role of the UNO creates negative attitudes among specialist officers that ultimately hinder the process of coordination in the Upazila (Ahsan \& Panday, 2013; Ali, 1987). When elected representatives are found in UZP, new dimensions of conflict between UZPC and UNO have arisen. In this context, the UNO tries to maintain a good relationship with MPs where the specialist officers prefer UZPC due to having the conflicting relations with the UNO that create new types of dimensions at Upazila level (Zamil, 2012; Ahmed et al., 2011).

\section{Role of partisan UZP in local coordination}

Historically, the local government system of Bangladesh is utilized by the all ruling parties for their own interest (Rahman, 2013; Ahmed et al., 2011; Huque, 1988). As a result, a strong self-reliant local government has not been developed yet. Despite these limitations, the government officials and the elected representatives of the UZP started to work together at local level in 1985 when the first UZP elections were held but UZP elections remained redundant even after democracy was re-established in 1991. It was again re-established in 2009 through a third UZP election. The third UZP (2009-2014) for the first time passed its tenure under the amended UZP Act in 2009, and with its continuation, the $4^{\text {th }}$ UZP election was held in 2014 through direct elections. Although it was a non-partisan election on paper, but there were political flavors with many candidates (Karim \& Rashid, 2016). It was found that the ruling Awami League-backed candidates won a total of 220 UZPC seats, while BNP won 158, Jamaat-e-Islami 36, Jatiya Party 3 , and rebels of two major parties, independents and aspirants from other parties 40 (https://nextnewsbd.wordpress.com/tag/upazila-election/) which shows the clear essence of a partisan character. Even in Bangladesh, other local polls like 'City Corporations' and 'Union Parishad' elections were held in the recent past with the clear political identity of candidates although they used no party symbols (Rahman \& Nasrin, 2017). Eventually, in 2015 the government took the decision to hold all local government elections on a partisan basis for the first time in Bangladesh (Mamun, 2015). Following this, the 9th UP elections were held in 2016 across the country under partisan provisions. Since there were clear political identities of elected representatives of the $4^{\text {th }}$ UZP who were elected in 2014, the government decisions of partisan local polls in 2015 practically converted them to act as a partisan UZP (Rahman \& Nasrin, 2017).

Chowdhury (2015) found that the political parties of Bangladesh are not only non-democratic but also a blind patriarchy, by which the political party of those in power systematically politicizes every institution and tries to create strong control by distributing authority to their party representatives by utilizing state machineries and public resources (cited in Rahman \& Nasrin, 2017). In this context, LG representatives are those who are elected under the partisan election, and they maintain a strong connection with the central government as well as their party leaders (Chowdhury, 2015). Another serious problem discovered is that the local 
administration is now chaired by a partisan person who makes decision in favor of his/her own party campaigners (Rahman \& Nasrin, 2017). Besides that, the local project distributions among the UPs by UZP depend on the political affiliation of UP Chairmen (Rahman \& Nasrin, 2017) under this new arrangement. The anxieties are that these local partisan UZP representatives are going to be in the queue for national level politics competing with existing MPs (Rashid, 2015), which creates confrontation among the party leaders at the local level and which creates coordination problems at the grassroots (Rahman \& Nasrin, 2017; Chowdhury, 2015; Rashid, 2015).

During the partisan local polls, a local MP who was the part of legislature was interfering in the nomination process of local government elections not only to ruin the local governance but also to control the local politics in favor of him/her (Chowdhury, 2015; Rashid, 2015). Furthermore, since the last UZP election was openly party backed and the last UP election was partisan legally, the ruling party was adamant in regards to capturing most of the seats for controlling the local politics through utilizing government machineries as well as illegal power demonstration by their party followers (Rahman \& Nasrin, 2017). Unfortunately massive violence, record deaths and uncontested elected Chairman, election frauds and irregularities, reluctant role of the Election Commission, and strong dominance by the ruling party in the electoral system were common phenomena in the last and maiden partisan LG election that was undoubtedly worse than any other LG election in the history of Bangladesh (Rahman \& Nasrin, 2017). As a result, a long historic stable local administration is dominating by the partisan leaders, in most cases, by the ruling party. Moreover MPs consider UZPC as their rising competitor in national politics, subsequently the relationship between ruling MPs and ruling UZPC are found to be competitive, conflicting rather than cooperative in local coordination, with few exceptions (Rahman \& Nasrin, 2017; Zamil, 2012), and which creates obstacles in local coordination.

\section{Conclusions and Recommendations}

Historically, colonial attitudes over the administration of Bangladesh have had huge impacts. During this period, bureaucrats dominated the local elected politicians in maintaining the local affairs by the influence of the British rulers and this continued until 1982. Even after the emergence of Bangladesh, MPs were not agreed on decentralizing authority to locally elected representatives due to losing their control over the local administration. But when the militarybacked government came into power, they focused the political support base from rural institutions through establishing some sorts of decentralization. Through the provision of the Upazila system in 1982, the politicians gained some authority to control local administration in the name of decentralization. It was undertaken to create strong local support at rural level in favor of the existing military government, not for the betterment of the local populace in the true sense. Since bureaucrats were not used to working under local politicians, they were not happy accepting the elected politicians over them. Consequently, competition and conflicts arose, compared to the cooperation in most 
cases, and which eventually effect on UZP activities. But the UZP were not functioning continuously, due to non-cooperation by the MPs as well as the negative intentions of the government over the UZP. After long time, a third UZP was formed through direct elections in 2009 under the amendment of the UZP Act of 1998 and it passed its full tenure (2009-2014) for the first time. At this moment, the $4^{\text {th }}$ elected UZP (2014-2019) are also functioning. To make it a success, the government had to enact some rules, orders and provisions. Among these, the compulsory advisory role of an MP over the UZP which was confirmed by the amendments of 2009 and 2011 over the UZP Act 1998 and the partisan local polls provision of 2015 have changed the total scenario. At the moment, politicians are the dominating agent in the local administration according to the law, but the administrators are not happy at accepting these sorts of changes. On the other hand, the MPs are found to be controlling their dominance over local politics and administration through practicing their legal authority as per UZP rules. Subsequently, there is a triangular conflict among MPs, UZPC and transferred department officials, including the UNO, which slows down local development. Through this rigorous literature review, we found a number of factors which are outlined by inter- and intra-organizational perspectives (see Figure 2) which negatively affect the local coordination of Bangladesh. Despite these existing problems, now the party-backed UZP representative of the practically and legally converted partisan UZP are found to be competitive and conflicting with transferred departments, including UNO and MPs, in terms of establishing him/herself as supreme in the local administration, as well as in strong political positions in the local and national politics, which creates mistrust and competition among them. These sort of competitive and conflicting relationships ultimately effect local coordination in respect of both of inter- and intra-organizational perspectives.

Figure 2

\section{Factors associated with local coordination in Bangladesh}

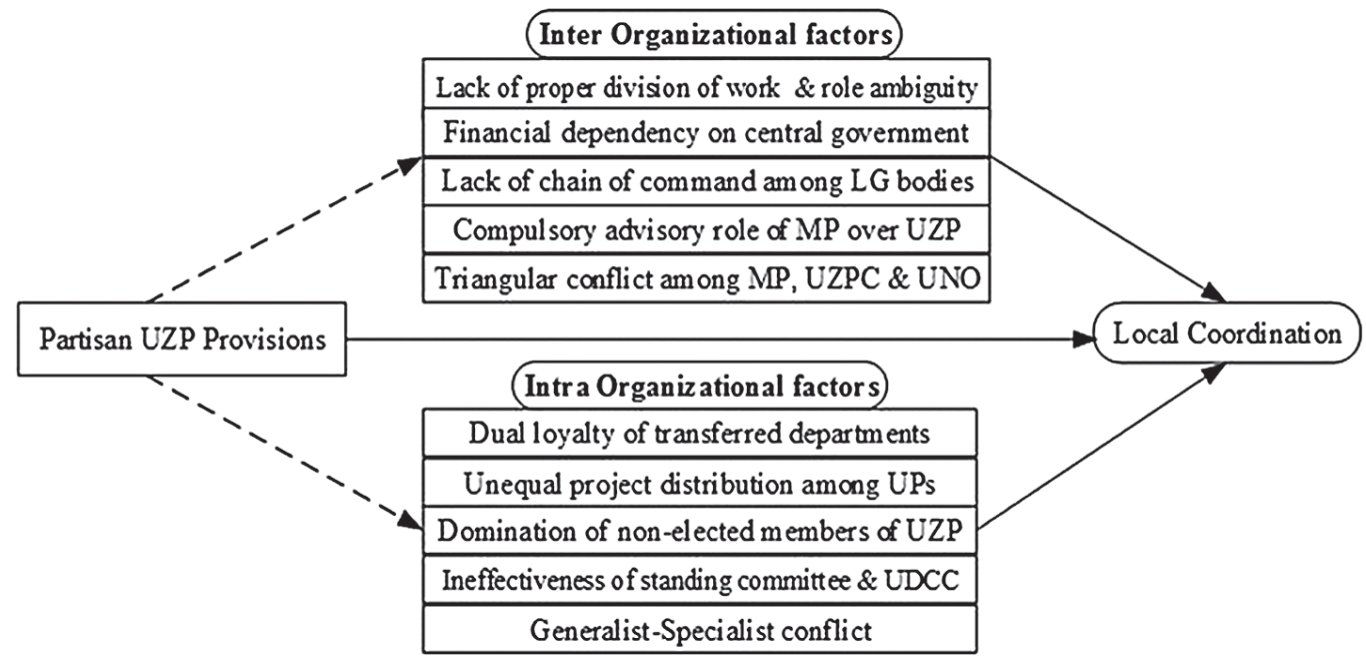

Own construction, 2018 
After reviewing the findings of this study, it is shown that most of the factors that negatively influence local coordination are legal issues, rather than political and administrative; but these legal provisions are made by the politicians. Among these, role ambiguity, dual accountability of transferred departments, compulsory advisory role of MP over UZP, lack of chain of command among LG bodies, less financial control of UZP, lack of clear supervision for distributing the projects among UPs, and provisions of partisan LG elections are the legal issues that may have the opportunity for revision and reform by the government with the consultation of all stakeholders, not only for the better coordination at local level but also to ensure local political harmony. Others factors which are identified through this study are also the by-product of legal provisions. Although, local public service delivery and local level development planning and execution is dependent on the harmonious relationships among UZP, transferred departments and MPs, this study found mistrust and clashes between the politicians and administrators that should be addressed for not only proper coordination but also for ensuring political coherence at the local level. In this regard, the government should change their mental egoism towards establishing self-reliant UZP where mutual adjustment should be ensured between politicians and administrators through taking proper legal changes according to the identified factors and justifying ambiguous matters instead of the political utilization of UZP in favor of their own interests. On the other hand, under the partisan local government election is not possible to arrange a free, fair and credible way under the ruling party considering the prevalent political culture of Bangladesh (Chowdhury, 2015). When an elected partisan LG was established through massive violence, election fraud and irregularities and strong dominance of the ruling party during partisan UP election in 2016, it not only increased the competition and conflict among the stakeholders but also the domination of a patriarchy was observed in local development activities (Rahman \& Nasrin, 2017). As a result, non-political citizens lost the fair opportunity to get services from a partisan LG in most cases. In this regard, the government can rethink withdrawing the decision of partisan LG elections considering the negative consequences of these over Upazila Administration and the conflicting political culture of Bangladesh. However, the major factors that affect local coordination have been identified through this literature review based on qualitative data. It was not possible, however, to measure the dominant factors statistically and the degree of influence of these factors on local coordination, which may guide the government to set priorities which can be explored further through a quantitative survey.

\section{Acknowledgement}

The corresponding author is grateful to the CAS-TWAS Presidents Fellowship authority and the other two authors are also thankful to the Chinese Scholarship Council for providing financial support during $\mathrm{PhD}$ and master study respectively 


\section{REFERENCES}

1. Ahmad, A.J.U.M. (1991). Problems of Co-Ordination in Upazila Administration in Bangladesh. Public Administration and Development, vol. 11, no 1, pp. 25-38.

2. Ahmed, E. (1980). Bureaucratic Elites in Segmented Economic Growth: Pakistan and Bangladesh. Dhaka: University Press Limited.

3. Ahmed, M.U. \& Rahman, M.M. (2012). A Critical Analysis of Influences of Central-Local Governmental Relations on Small-Scale Development Programs and Projects of Ongoing Upazila Parishad in Bangladesh, Lok Proshason Samoeeky, Yearly Issue 2010.

4. Ahmed, N. (1988). Experiments in Local Government Reform in Bangladesh. Asian Survey, vol. 28, no 8, pp. 813-829.

5. Ahmed, N. (2009). Bureaucracy and Local Politics in Bangladesh: a Study in Roles and Relationship. Dhaka: AHDP.

6. Ahmed, N., Ahmed, T. \& Faizullah, M. (2011). UNDP Report on Working of Upazila Parishad in Bangladesh: A Study of Twelve Upazilas.

7. Ahmed, T. (2010). Bodoler Kichu Joruri Path. In: Je Poriborton Joruri (In Bangla). Edited by Motiur Rahman. Dhaka: Prothoma Prokashon.

8. Ahsan, A.H.M.K. \& Panday, P.K. (2013). Problems of Coordination in Field Administration in Bangladesh: Does Informal Communication Matter? International Journal of Public Administration, vol. 36, no 8, pp. 588-599.

9. Ali, A.M.M.S. (1987). Decentralization for Development: Experiment in Local Government Administration in Bangladesh, Asian Survey, vol. 27, no 7, pp. 787-799.

10. Ali, S.M. (1983). Decentralisation and People's Participation in Bangladesh. Dhaka: National Institute of Public Administration.

11. As-Saber, S.N. \& Rabbi, M.F. (2009). Democratisation of the Upazila Parishad and Its Impact on Responsiveness and Accountability: Myths versus Realities, JOAAG, vol. 4, no 2.

12. Blair, H.W. (1985). Participation, Public Policy, Political Economy and Development in Rural Bangladesh 1958-1985. World Development, vol. 13, no 12, pp. 1231-1247.

13. Booth, A., Papaioannou, D. \& Sutton, A. (2012). Systematic Approaches to a Successful Literature Review. London: SAGE.

14. Choudhury, D. (2015). Dec 22, Local Government Elections in Bangladesh and Democracy. The Daily New Age. Available at: http://newagebd.net/186396/local-government-electionsin-bangladesh-and-democracy/ (accessed: 03 September, 2018).

15. Demir, T. \& Reddick, C.G. (2012). Understanding shared roles in policy and administration', Public Administration Review, vol. 72, no 4, pp. 526-536.

16. Finer, H. (1941). Administrative Responsibility in Democratic Government. Public Administration Review, no 1, pp. 335-350.

17. Friedrich, C.J. (1940). Public Policy and the Nature of Administrative Responsibility, In: C.J. Friedrich and E.S. Mason (eds.). Public Policy, Cambridge: Harvard University Press.

18. GOB (Government of Bangladesh) (1998). The Upazila Parishad Act (In Bangla), Local Government Division, Ministry of Local Government, Rural Development and Cooperatives, Dhaka.

19. GOB (Government of Bangladesh) (2010). Upazila Parishad Manual (In Bangla), Local Government Division, Ministry of Local Government, Rural Development and Cooperatives, Dhaka. 
20. GOB (Government of Bangladesh) (2011). Upazila Parishad (Songshodhon) Ain 2011, 1 December. Dhaka: BG Press.

21. Hagen, T. P. \& Sørensen, R. (1997). Kommunal organisering. Tano-Aschehoug. Oslo.

22. Hansen, K.M. \& Ejersbo, N. (2002). The Relationship between Politicians and Administrators: A Logic of Disharmony, Public Administration, vol. 80, no 4, pp. 733-750.

23. Hossain, M.A., Sikder, M.U. \& Alam, M.S. (2013). The Relationships between Elected Members \& Government Officials of Upazila Parishad Dhamrai Upazila: A Case Study, Asian Studies: Jahangirnagar University Journal of Government and Politics, no 32.

24. Huq, Manzu-Nul, S.K.M., Md. Ahmed, K., Md. Moqbul, A. \& Muslim, S.N. (1987). The Problem of Coordination in Upazila Administration: A Case Study of Two Upazilas. Dhaka: Bangladesh Public Administration Training Center.

25. Huque, A.S. (1988). Politics and Administration in Bangladesh: Problems of Participation. Dhaka: University Press Limited.

26. Huque, A.S. (1985). The Politics of Local Government Reform in Rural Bangladesh. Public Administration and Development, vol. 5, no 3, pp. 205-217.

27. Huque, A.S. (1992). Performance of Local Councils in the Collection of Revenue in Bangladesh. Public Administration and Development, no 12, pp. 343-354.

28. Huque, A.S. (2011). Some Neglected Aspects of Performance in Field Administration in Bangladesh. International Journal of Public Administration, vol. 34, no 5, pp. 318-328.

29. Jacobsen, D.I. (2003). Politico-Administrative Conflict at the Local Level: Determined by the Degree of Central Government Regulation. Local Government Studies, vol. 29, no 4, pp. 95-116.

30. Jahan, F. \& Shahan, A.M. (2008). Politics-Bureaucracy Relationship in Bangladesh: Consequences for the Public Service Commission. Public Organization Review, no 8, pp. 307-328.

31. Jennings, E.T. (1994). Building Bridges in the Intergovernmental Arena: Coordinating Employment and Training Programs in the American States. Public Administration Review, vol. 54, no 1, pp. 52-60.

32. Jesson, J. (2011). Doing your Literature Review: Traditional and Systematic Techniques. Los Angeles: Calif; London: SAGE.

33. Karim, R. \& Rashid, A. (2016). June 06, The Evaluation of Political Parties: The Electoral System has been mismatched (In Bengali), The Daily Prothom Alo. Available at: http://www. prothom-alo.com/bangladesh/article/879667/ (accessed: 03 September, 2018).

34. Kettl, D.F. (2003). Contingent Coordination: Practical and Theoretical Puzzles for Homeland Security. American Review of Public Administration, vol. 33, no 3, pp. 253-277.

35. Khan, N.A. (2001). The Political Economy of Decentralised Local Governance in Bangladesh: A Retrospect. Indian Journal of Social Work, vol. 62, no 1, pp. 90-105.

36. Khan, N.A. (2016). Challenges and Trends in Decentralised Local Governance in Bangladesh, ISAS working papers, No. 222, 22 January 2016, Institute of South Asian Studies, National University of Singapore.

37. Malone, T.W. \& Crowston, K. (1994). The Interdisciplinary Study of Coordination, Computing surveys, vol. 26, no 1, pp. 87-119.

38. Mamun, S. (2015). Local Govt Polls to Become Partisan. Dhaka Tribune. October 13. Available at: http://archive.dhakatribune.com/bangladesh/2015/oct/13/local-govt-polls-becomepartisan (accessed: 03 September, 2018).

39. Mintzberg, H. (1979). The Structuring of Organizations: A Synthesis of the Research. London: Prentice-Hall International, Inc. 
40. Mojumdar, B.A. (2010) Contours of Democratic Consolidation. In: 40 Years of Bangladesh Way Forward Volume 1: Democracy and Governance. $20^{\text {th }}$ Anniversary Publication of the Daily Star, Bangladesh.

41. Morshed, M.M.R. (1997). Bureaucratic Response to Administrative Decentralisation: A Study of Bangladesh Civil Service. Dhaka: University Press Limited.

42. Mosher, F.C. (1982). Democracy and the Public Service. New York: Oxford University Press.

43. Mouritzen, P.E. \& Svara, J.H. (2002). Leadership at the Apex: Politicians and Administrators in Western Local Governments. Pittsburgh: University of Pittsburgh Press.

44. Mutebi, A.M. (2004). Recentralising while Decentralising: Central-Local Relations and "CEO" Governors in Thailand. The Asia Pacific Journal of Public Administration, vol. 26, no 1, pp. 33-53.

45. Nadiruzzaman, M. (2008). Rural Local Government and State Politics in Bangladesh. Durham Theses, Durham University.

46. Page, E. (1991). Localism and centralism in Europe. New York: Oxford University Press.

47. Panday, P.K. (2011). Local Government System in Bangladesh: How Far is it Decentralized? LEX LOCALIS - Journal of Local Self-Government, vol. 9, no 3, pp. 205-230.

48. Panday, P.K. (2014). Central-Local Relations, Inter-Organisational Coordination and Policy Implementation in Urban Bangladesh. Asia Pacific Journal of Public Administration, vol. 28, no 1 , pp. 41-58.

49. Phillips, A. (1996). Why Does Local Democracy Matters? In: Pratchett, L. \& Wilson, D. (eds). Public Administration Review, no 37, pp. 659-670.

50. Radaelli, C.M. (2008). Europeanization, Policy Learning, and New Modes of Governance. Journal of Comparative Policy Analysis, no 10, pp. 3.

51. Rahman, M.M. \& Nasrin, S. (2017). Maiden Partisan Rural Local Government Elections: Bangladesh Experience. Journal of Public Administration and Governance, vol. 7, no 1.

52. Rahman, M.S. (1997). Restructuring Local Government in Bangladesh: An Overview. Bangladesh Public Administration Review, vol. 1, no 1, pp. 27-46.

53. Rahman, M.S. (2012). Upazila Parishad in Bangladesh: Roles and Functions of Elected Representatives and Bureaucrats. Commonwealth Journal of Local Governance 11.

54. Rahman, M.S. (2013). Role of the Members of Parliament in the Local Government of Bangladesh: Views and Perceptions of Grassroots in the Case of Upazila Administration. Public Organization Review, no 13, pp. 71-88.

55. Rahman, M.S. (2014). Bureaucratic Perceptions to the Politics-Bureaucracy Relations in Bangladesh: A Moral Dilemma in between Political Neutrality and Responsiveness. Asian Journal of Political Science, vol. 22, no 3, pp. 252-267.

56. Rahman, M.S. (2015). Politics-Bureaucracy Relations, Governance and Development in Bangladesh: The Case of Local Government. PhD Dissertation to Heidelberg University, Germany.

57. Rashid, A. (2005). The Politics of Administrative Decentralization in Bangladesh. Canadian Journal of Development Studies, vol. 26, no 4, pp. 781-798.

58. Rashid, H. (2015). December 14, EC is not maintaining its own formulated rules (In Bengali). The Daily Prothom Alo. Available at: http://www.prothom-alo.com/bangladesh/article/711865/ (accessed: 06 September, 2018).

59. Robinson, D., Hewitt, T. \& Harris, J. (2000). Why inter-organizational relationships matter. In: D. Robinson, T. Hewitt, and J. Harris (eds.). Managing Development - Understanding Inter-Organizational Relationships. London: Sage. 
60. Rondinelli, D.A. (1981). Government Decentralization in a Comparative Perspective. Theory and Practice in Developing Countries. International Review of Administrative Sciences, no 47, pp. 133-145.

61. Rondinelli, D.A. (1992). Implementing Decentralization Programmes in Asia: A Comparative Analysis. In: B. Smith (ed.). Progress in Development Administration. Chichester: John Wiley.

62. Sarker, A.E. (2003). The Illusion of Decentralization: Evidence from Bangladesh. The International Journal of Public Sector Management, vol. 16, no 7, pp. 523-540.

63. Siddiqui, K. (2005). Local Government in Bangladesh. Edited by Kamal Siddiqui. Bangladesh, Dhaka-1000: University Press Limited.

64. Silverman, D. (2011). Qualitative Research. 3rd Ed., Thousand Oaks: SAGE Publications.

65. Sowdagar, M.A. (2010). Reintroducing Upazila System in Bangladesh: Quest for Autonomy, Development Compilation, vol. 4, no 1.

66. Spicer, Z. (2015). Cooperation, Coordination and Competition: Why do Municipalities Participate in Economic Development Alliances? Canadian Public Administration, vol. 58, no 4, pp. 549-573.

67. Svara, J.H. (1985). Dichotomy and Duality: Re-Conceptualizing the Relationship between Policy and Administration in Council-Manager Cities. Public Administration Review, vol. 45, no 1, pp. 221-232.

68. Svara, J.H. (1998). The Politics-Administration Dichotomy Model as Aberration. Public Administration Review, vol. 58, no 1, pp. 51-58.

69. Svara, J.H. (1999). Complementarity of Politics and Administration as a Legitimate Alternative to the Dichotomy Model, Administration \& Society, vol. 30, no 6, pp. 676-705.

70. Svara, J.H. (2001). The Myth of the Dichotomy: Complementarity of Politics and Administration in the Past and Future of Public Administration. Public Administration Review, vol. 61, no 2, pp. 176-183.

71. Svara, J.H. (2006). The Search for Meaning in Political-Administrative Relations in Local Government. International Journal of Public Administration, vol. 29, no 12, pp. 1065-1090.

72. The Daily Star (2009). MP's advisory role to create chaos, The Daily Star, 8 April, Dhaka.

73. Westergaard, K. \& Alam, M.M. (1995). Local Government in Bangladesh: Past Experiences and Yet Another Try. World Development, vol. 23, no 4, pp. 679-690.

74. Whettenhall, R. \& Thynne, I. (2010). Symposium on Ownership in the Public Sphere. International Journal of Public Policy, vol. 5, no 1.

75. Zafarullah, H. (2005). Local Development Planning: Political and Bureaucratic Imbroglio. In: M. M. Khan and H. Zafarullah (eds). Bureaucratic Ascendancy: Bangladesh. South Asian Publishers, New Delhi, Chapter 9.

76. Zamil, A. (2012). Annual Development Programme (ADP) Grants for Upazila Parishads: Role of Upazila Nirbahi Officer (UNO) in the Planning and Implementation Process, Unpublished thesis of Master in Public Policy and Governance Program under Department of General and Continuing Education. Bangladesh, Dhaka: North South University.

77. 6, P. \& Bellamy, C. (2012). Principles of Methodology - Research Design in Social Science. Thousand Oaks: Sage Publication. 